\title{
Projected Rainfall Variability Based on PRECIS Regional Model
}

\author{
ANILA MEMON*, KAMRAN ANSARI*, ARSHAD ASHRAF**, MUHAMMAD MUNIR BABAR*, AND \\ ABDUL GHANI SOOMRO*
}

RECEIVED ON 10.07.2018 ACCEPTED ON 17.08.2018

\begin{abstract}
The present study indicates the potential projected variation of decadal mean rainfall over Kohistan region of Sindh Province, Pakistan. Precipitation variability is a crucial climatic factor that affects human health and their settlements. In this study, the precipitation variability associated with climate change in Kohistan region, Sindh, Pakistan is simulated using the PRECIS regional climate modeling system. The study analyses the precipitation variability in the future for two spells (2021-2050 and 20712099) with respect to the past (1961-1990) climate under the baseline ECHAM5 dataset for A1B Scenario at a resolution of $25 \times 25 \mathrm{~km}$. Based on this analyses, the precipitation scarcity is projected for 2021-2050 and 2071-2099 decades. The projected results showed a serious precipitation variation and shortfall of 12.60, 53.98, and 48.19\% during 2031-2040,2041-2050 and 2081-2090 decades respectively as compared to baseline (1961-1990). The analyzed situation would be harmful to the water resources and agricultural production in the region during the shortfall, which imposes the adverse effect on the recharge of groundwater and quality. That might cause of long drought spell in the region. While during the 20212030 decade shown slight influence on the potential of hill torrents and groundwater recharge. However, the results reveal for the period of 2071-2080 and 2091-2099, the extreme floods with 60.50 and $70.50 \%$ are projected as compared to baseline 1961-1990. The increasing trend of precipitation indicates additional recharge of fresh groundwater and quality, with increasing level of aquifers, subsequently more agricultural production would be expected with alternate employment opportunities in the water sector. The projected results, indicating the decadal scenarios of the drought and wet spells in the region by the precipitation variation, which may impact on the hill torrents, groundwater and agricultural production, and employment opportunities. These quantitative projections should enable policymakers and stakeholders to plan for future measures.
\end{abstract}

Key Words: Climate Change, Precipitation Variability, PRECIS Model, Water Resources Prediction, Pakistan; Hill Torrents.

\section{INTRODUCTION}

The change in current and projected weather inconsistency play's key role in long-lasting planning and management in the water resources sector, especially those areas which are fully dependent on the precipitation [1].
Climate change effects have been observed in Pakistan as significant variations in rainfall patterns and stream flows, increase in extreme events (floods/droughts), fluctuations in temperature, humidity, etc. According to the German watch Global Climate Risk Index, Pakistan

Authors E-Mail: (aneelahameem@gmail.com, mashr22@yahoo.com,kansari.uspcasw@faculty.muet.edu.pk, mmunirbabar.uspcasw@faculty.muet.edu.pk,ag2005parc@gmail.com

* US-Pakistan Center for Advanced Studies in Water, Mehran University of Engineering \& Technology, Jamshoro, Pakistan.

** Scientific Officer, Pakistan Agricultural Research Council, Islamabad, Pakistan.

This is an open access article published by Mehran University Research Journal of Engineering and Technology, Jamshoro under the CC by 4.0 International License. 
has been listed among the ten countries most affected by climate change [2].The effect of environmental change influences distinctive parts of the country, including the rustic, and along the coastal and dry atmospheric parts, where the susceptibility of poor societies is expanding. Access to foodstuff, water, and different assets is the primary task in those localities [3-4]. Women, in particular, bear more of the burden on the rural communities in Pakistan as their involvement in the scarce water,requires walking for long distances in extreme temperatures to collect water for their household chores[5].

The management of hill-torrent (rainwater harvesting from the mountains) in many regions of Pakistan is seriously affected by climate change. The fluctuation of hill torrents poses a great challenge for sustainable agriculture development in Sindh Province [6]. The dissimilarities of ephemeral rivers lead the hazardous situation for the lower riparian due to low and high flows followed by the drought spell and extreme floods [7].

Moreover, climate change has significantly influenced the temperature in the region. Annual average temperatures in Pakistan are projected to increase by $5.0^{\circ} \mathrm{C}$ by the end of the $21^{\text {st }}$ century. Temperature rise is likely to cause evident variations in the hydrological cycle, which bring about unstable rainfall duration and cropping trend, starvations, and water accessibility times [8]. This would cause drastic loss of natural resources and biodiversity [9]; increase the demand on water for localities, animals, agriculture activities and industrial purposes eventually pose a threat to future food security [10]. Hence, the increase in water requirement would be about $1 \frac{1}{2}$ times more than the present situation [10]. Additionally, this may influence the social life [11].

The prediction of climatic conditions for a large number of years/decades with sufficient accuracy is a tremendous task [12]. Several attempts have been carried out to investigate the influence of climate change and predict future climate extremes over many regions in the world [13-16].

Ospina and Heeks [17] projected 35.13, 0.95, 12.58, 53.98 and 2.93 it is not clear whichperiods/locations these numbers correspond to percent shortfall of rains for the period of 2021-2050 and 2071-2099 in Sindh Province, Pakistan. Nigel [18], conducted a study and used the data from 1995, he revealsthat about 1,400 million people were surviving in water-stressed and watershed areas. Most of the peoples were residing in Southwest Asia with less than $1000 \mathrm{~m}^{3} /$ capita of water per year. To compile the study, the author used SRES (Socio-Economic Scenarios) and climate change projection models, as well as hydrological models, coupled with watershed for estimating present and past features of water resources. Results compiled indicated that by 2055 , more than 5.6 billion people would be living in water-depleted catchment areas.

It may take numerous years to establish a regional climate system after extreme incident depending on the harshness of droughts or floods [19]. Hence, water resources appraisal is essential in most critical regions where global warming may cause genuine devastations [7]. It helps policymakers and stakeholders make possible measures $[9,20]$. Accordingly, this study focused on the climate change impact in the Kohistan region of Sindh Province, Pakistan. The study objective is to investigate and predict variability in precipitation patterns in this region for the next 60 years (2021-2050 and 2071-2099) using PRECIS regional modeling system in order to identify options for future adaptation in this region. Several studies have used the PRECIS regional modeling system to assess climate change impacts and provide regional climate scenarios worldwide (e.g. [17,21-30]. The reported accuracy level is empowering and supportive of future development in the various aspects of water demand. The PRECIS model

Mehran University Research Journal of Engineering \& Technology, Volume 38, No. 2, April, 2019 [p-ISSN: 0254-7821, e-ISSN: 2413-7219] 
combined with GIS/RS (Geographic Information System)/ (Remote Sensing) and shown accurate gap filling results of future projections precipitation inconsistencies and trend [31]. The use of a regional climate model e.g. [32-33] can provide a convenient tool for policymakers to manage this adversity and resolve climatic and geographical characteristics.

\section{MATERIAL AND METHODS}

\subsection{The Study Area}

The study area covers 11,426 square kilometers, and it lies between longitudes from $67012-68027^{\circ} \mathrm{E}$ and latitudes from $25012-26095^{\circ} \mathrm{N}$ in the Kohistan region, in the western part of Sindh Province, Pakistan (Fig. 1). The area comprised of three administrative districts: Dudu 1,427 $\left(\mathrm{km}^{2}\right)$, Jamshoro $9057\left(\mathrm{~km}^{2}\right)$ and Thatta $942\left(\mathrm{~km}^{2}\right)$.

Though the selected area of study depends on rain-fed agriculture, groundwater is extracted for agriculture and domestic purposes. Even though the quantity and quality of the groundwater vary between wet and dry seasons, flash floods or hill torrents feed the aquifers and recharge them. The deep and shallow aquifers are being used by the local community. However, shallow aquifers are developed on the banks of natural streams. The region is

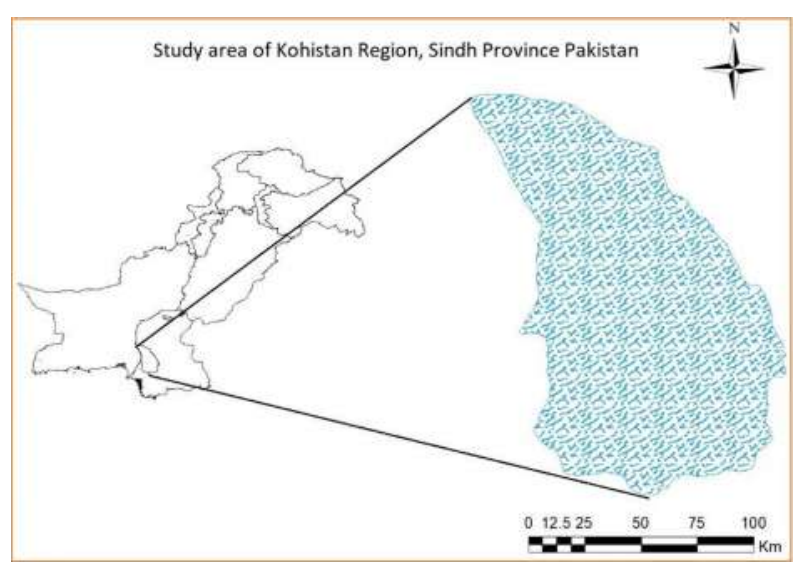

FIG. 1. STUDY AREA WITHIN THE GEOGRAPHIC BOUNDARIES OF PAKISTAN experiencing problems of water shortage and low crop yields, due to an escalation in temperature, inadequate water storage capacities, erratic and uneven precipitations followed by droughts.

\subsection{PRECIS Modeling}

In this study, the PRECIS Model (Meteorological Department, Hadley, UK) was used to predict the variability in precipitation patterns. The baseline ECHAM5 dataset for A1B Scenario was downloaded to $25 \times 25 \mathrm{~km}$ resolution using PRECIS Model from PMD (Pakistan Meteorological Department) and was then downscaled to the regional level. The model was associated with ArcGIS 10.3.1 to obtain the predicting results.

The baseline period for precipitation (1961-1990), has been used to forecast the impact of climate change and the results of future scenarios have been compared with the baseline scenario. However, using results of the climate change model for assessment of scenario structure, the baseline served as the reference period from which the demonstrated future change in environment was calculated as a percentage. The precipitation data for each decade has been used as a mean decadal in millimeters.

The data was collected in MS-Excel spreadsheets. Georeferencing of the acquired datasets, Geospatial interpolation, and extraction by the masking technique were used to downscale the entire data to map the baseline period of model data from 1961-1990. RS and GIStechniques were employed to enhance the presentation of the results and facilitate validating the climate model. The graphs based on the processed data were developed by MS-Excel to calculate and assess the results for projecting and changing circumstances of the study area. The data for sixty years in two different spells has been projected for 2021-2050 and 2071-2099. 
The interpolation of Kriging methodology was used in ArcGIS 10.3.1 version. It is the same process as used in the IDWM (Inverse Distance Waiting Methodology), that it weights the neighboring estimated values to calculate for projections for the unknown gauging stations. The governing Equation (1) of Kriging is as:

$Z^{\wedge}\left(S_{0}\right)=\sum_{i=1}^{N} \lambda i Z(s i)$

Where $Z\left(s_{i}\right)$ is the measured value at the $i^{\text {th }}$ location. $\lambda_{i}$ is an unknown weight for the measured value at the $\mathrm{i}^{\text {th }}$ location. $\mathrm{s}_{0}$ is the prediction location, and $\mathrm{N}$ is the number of measured values.

\section{RESULTS AND DISCUSSION}

The results revealed that the high range of rainfall (12.84$13.48 \mathrm{~mm})(13.02-13.5 \mathrm{~mm})$ occurred in the south-western part of Jamshoro District; and the low range of rainfall $(10.26-10.78 \mathrm{~mm})(10.28-10.89 \mathrm{~mm})$ occurred in the eastern parts of Dadu and Jamshoro Districts. The average rainfall amount for the entire study area during 1961-1990 is 11.61 mm (Fig. 2). The vulnerability of the Manchar Lake area due to rainfall occurrence was detected during the baseline period. This area received much less rainfall during the years 1961-1990.

Results of the first projected decade 2021-2030 showed a $1 \%$ shortfall of precipitation, which inflicts negligible impacts on the potential of hill torrents and groundwater recharge as compared to the baseline precipitation period (1961-1990) (Fig. 3(a-b)).

Fig. 4(a-b) illustrates the projected precipitation scenario of 2031-2040 which portrays an $87.4 \%$ rainfall during the reported period. The higher quantity of rainfall is expected to be in the range of 12.66-13.35 mm. This precipitation amount will be adequate to meet the basic needs of the entire study area. The area of Manchar Lake will receive the relatively higher amount of rainwater; while adjoining parts such as Khairpur Nathan Shah, Dadu, Sehwan, JhangaraBajara, etc. will receive adequate rain water to fulfill their respective water requirements. Subsequently, the runoff will contribute to the Indus River by adjoining parts of the above area. However, the precipitation in the command area of the Hub dam would be affected and receive a lower quantity of rainfall ranging from 7.05-8.48 $\mathrm{mm}$. The catchments of Hub dam will be affected and will receive only a small quantity of water through their upper catchments, during the reported period of 2031-2040.

The precipitation results for the future scenario (20412050 ) depict that during this decade $46.02 \%$ precipitation of the referenced baseline is predicted (Fig. 5(a-b)). This

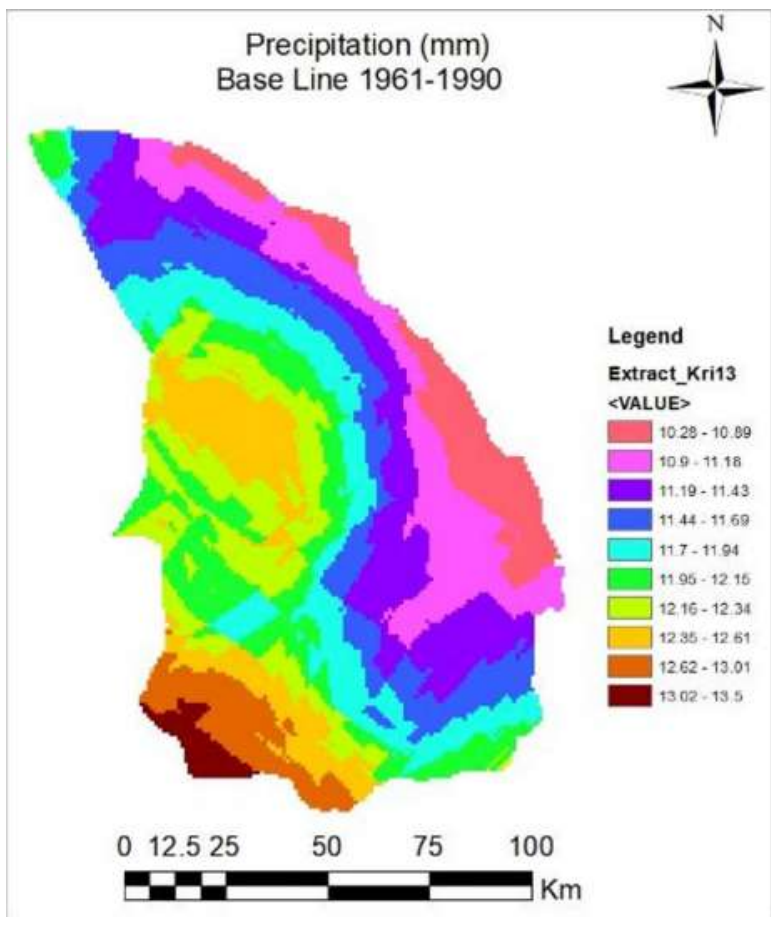

FIG. 2. AVERAGE PRECIPITATION OVER 1961-1990 PERIOD (BASELINE SCENARIO)

Mehran University Research Journal of Engineering \& Technology, Volume 38, No. 2, April, 2019 [p-ISSN: 0254-7821, e-ISSN: 2413-7219] 
scenario describes an acute rainfall dearth in the study area. The severely hit drought areas would be the north-

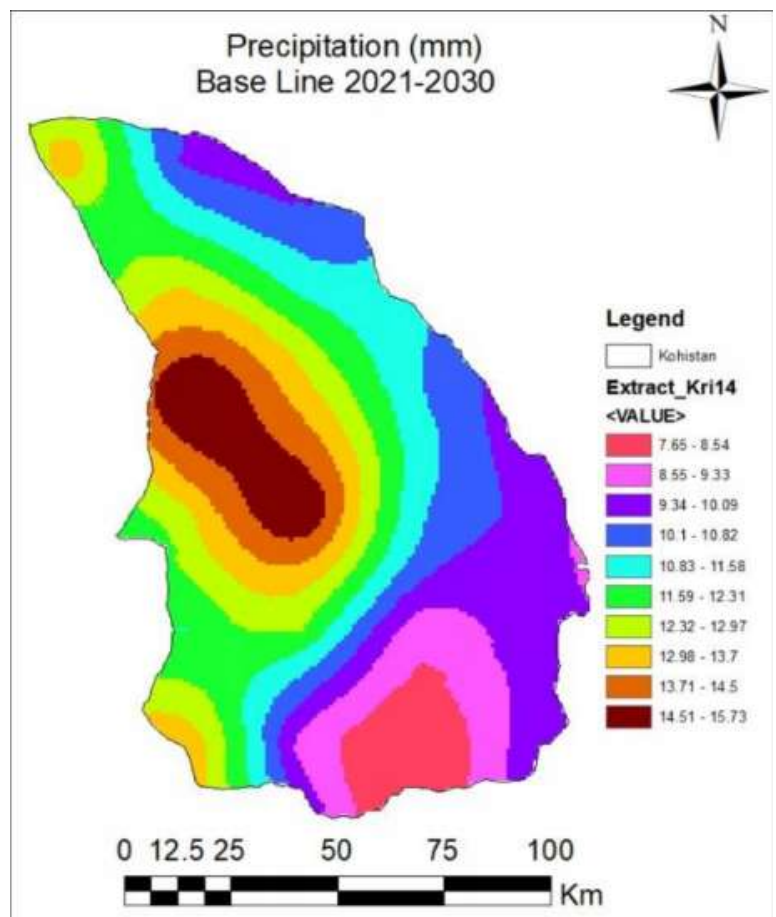

FIG. 3(a). AVERAGE PRECIPITATION IN THE STUDY AREA OVER (2021-2030) PERIOD

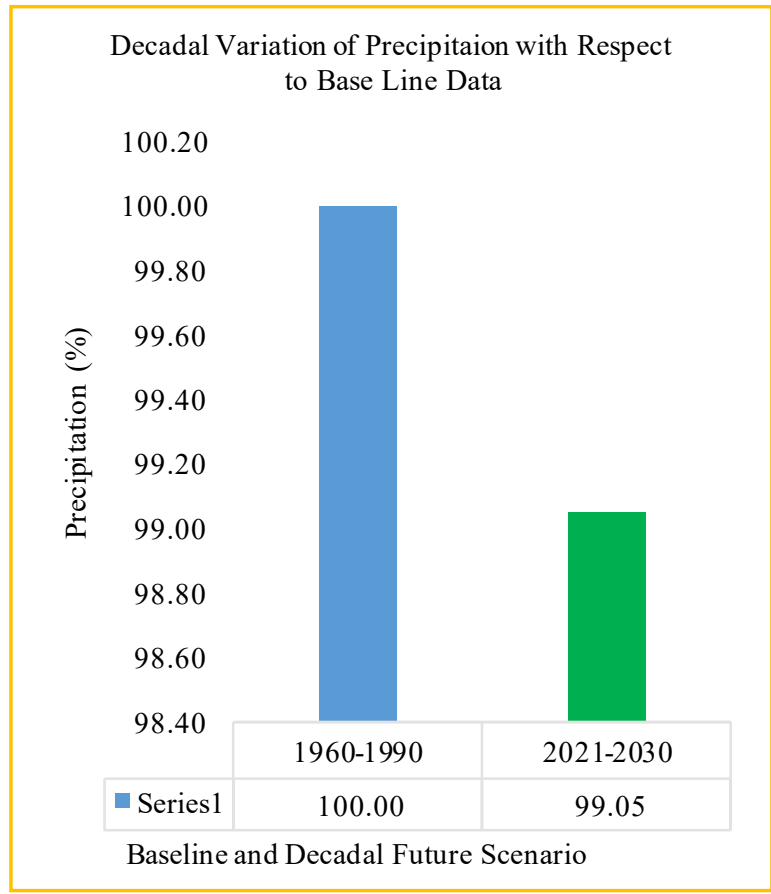

FIG. 3(b). PRECIPITATION SHORTFALLS COMPARED TO THE BASELINE SCENARIO east to south-east parts of Dadu district along with Manchar Lake, as well as Jamshoro, where only 3.37-4.43

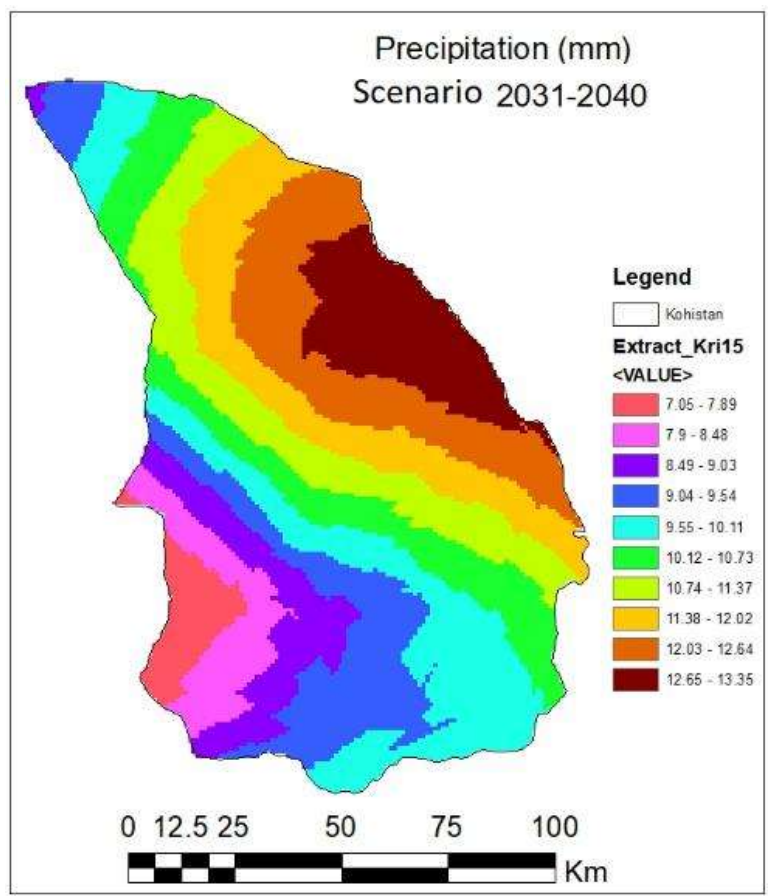

FIG. 4(a). AVERAGE PRECIPITATION IN THE STUDY AREA OVER (2031-2040) PERIOD

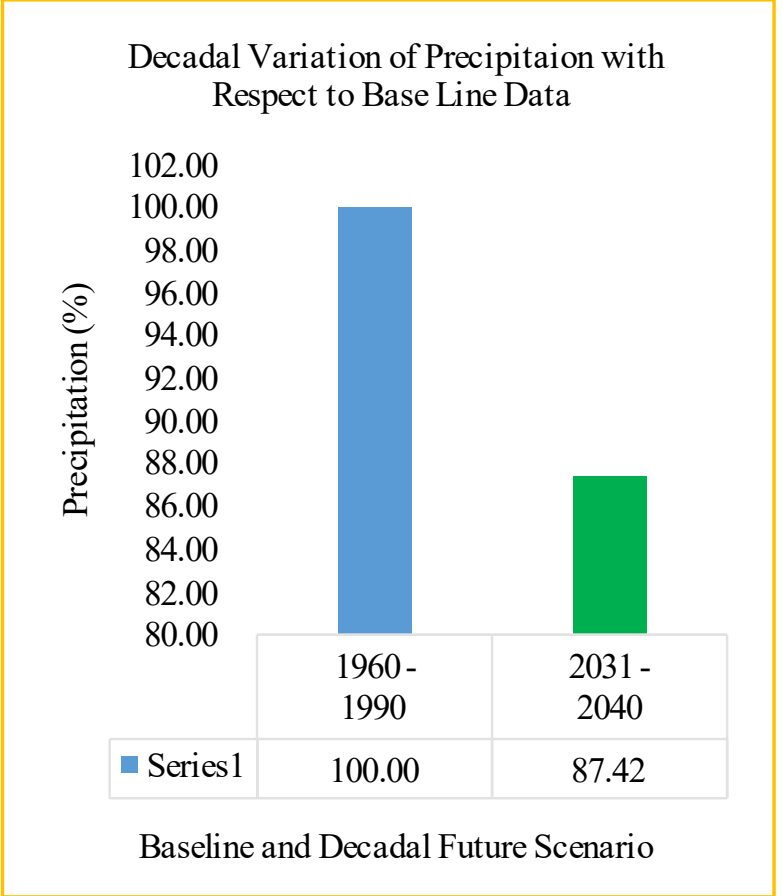

FIG. 4(b). PRECIPITATION SHORTFALLS COMPARED TO THE BASELINE SCENARIO

Mehran University Research Journal of Engineering \& Technology, Volume 38, No. 2, April, 2019 [p-ISSN: 0254-7821, e-ISSN: 2413-7219] 
$\mathrm{mm}$ of the normal precipitation is predicted. Overall, a $53.98 \%$ deficit of precipitation is forecasted in the study area during 2041-2050. That will harshly impact the agriculture and livestock of the area, and adversely affect the central part from north to south regions of the area, such as Gaj and Darwat Dam sites, Jamshoro, Thana Boula Khan, Sari, Mole, Nooriabad, Thatta, and Keenjhar Lake. The post effects of the situation could result in a long period of drought, which may cause an increased migration rate, due to unemployment in the water sector and increasing poverty.

Fig. 6(a-b) reveals the future precipitation scenario for the 4th decade (2071-2080). This scenario has predicted $160.411 \%$ rainfall compared to the baseline precipitation in the study area. The reported decade indicates the hazard floods in the study area. However, most of the rainfall is expected in the eastern and central region in districts Dadu and Jamshoro; and eastern part of Thatta region, no adverse effects on hill torrents and groundwater potential is expected, although the watershed of Hub dam could receive less quantity of runoff water as compared to other areas. The western border of the area will receive less rainfall. However, the hill torrents within Dadu, Sehwan, and JhangaraBajara, small and medium streams might contribute more water potential in the groundwater aquifer. The runoff from these areas will contribute to the Darwat Dam, as well many small dams in Rani Kot, Thana Boula Khan, Manchar Lake, and Keenjhar Lake and to the Indus River. The groundwater quality will be improved in the reported area, due to aquifer recharge through flash flood events. This decade has a huge quantity of water in the region which needs a good future planning and management to store water for the conservations in the drought season.
The Fig. 7(a-b) the precipitation results for the future scenario (2081-2090) depict that during this decade $48.19 \%$ precipitation of the referenced baseline is

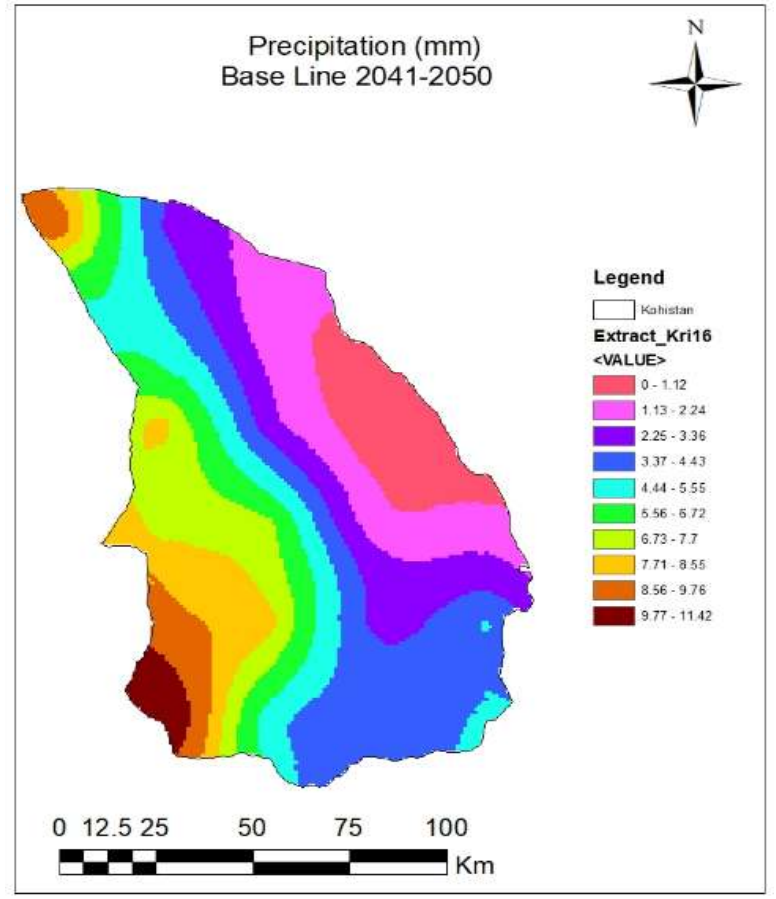

FIG. 5(a). AVERAGE PRECIPITATION IN THE STUDY AREA OVER (2041-2050) PERIOD

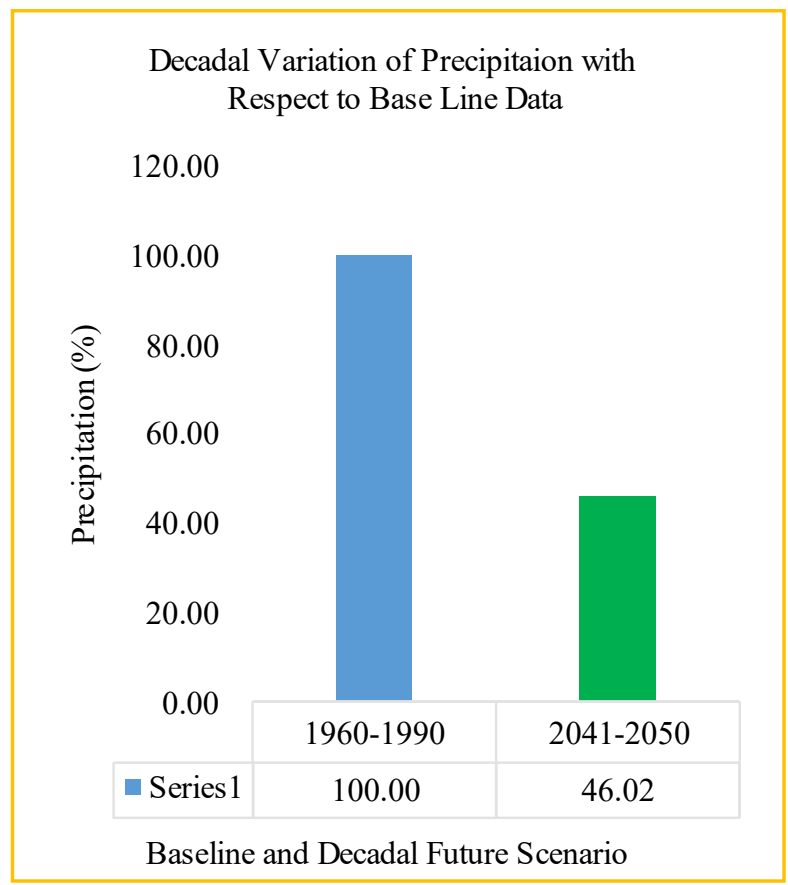

FIG. 5(b). AVERAGE PRECIPITATION IN THE STUDY AREA OVER (2041-2050) PERIOD

Mehran University Research Journal of Engineering \& Technology, Volume 38, No. 2, April, 2019 [p-ISSN: 0254-7821, e-ISSN: 2413-7219] 
predicted. This scenario describes an acute rainfall shortage in the study area. The harshly hit drought areas would be the central eastern parts of Dadu district, which

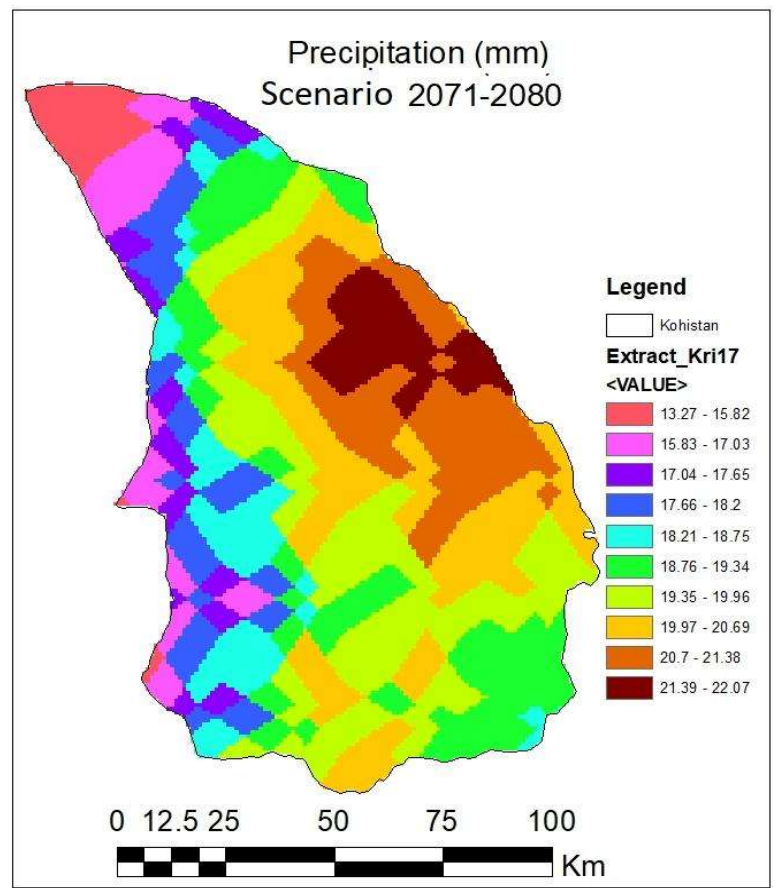

FIG. 6(a). AVERAGE PRECIPITATION IN THE STUDY AREA OVER (2051-2060) PERIOD

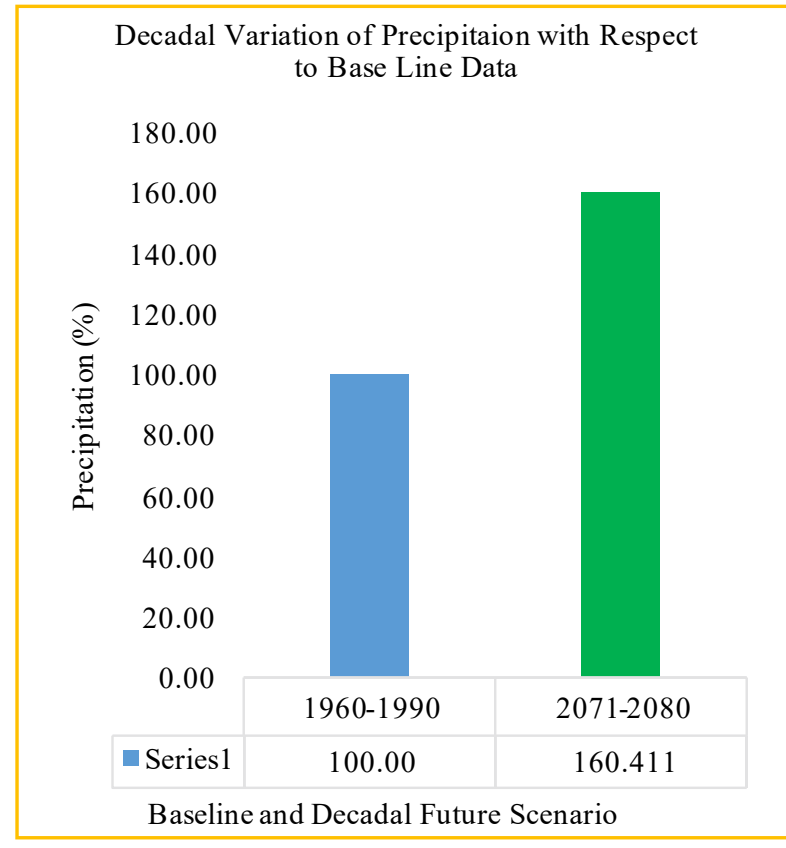

FIG. 6(b). PRECIPITATION SHORTFALLS COMPARED TO THE BASELINE SCENARIO affect command and catchment area of Manchar Lake in the region, as well as central part of the study area from north to south would be affected and the region will face a shortage of agriculture production. Groundwater abstractions will be overloaded due to that quality of the aquifers would be affected. The lower part of Jamshorodistrict would have more showers of precipitation as compared to other parts of the study area. Overall, a $48.19 \%$ deficit of precipitation is forecasted in the study area during 2081-2090. That will harshly impact the agriculture and livestock of the area, and adversely affect the central part from north to south regions of the area, such as Gorakh hill station, catchment of Gaj and Darwat Dam sites, Manchhar Lake, Jamshoro, Thana Boula Khan, Sari, Mole, Nooriabad, Thatta, and Keenjhar Lake. The post effects of the situation could result in a long period of drought, which may cause an increased migration rate, due to unemployment in the water sector and increasing poverty.

Results of the last decade forecast based on the baseline precipitation period (1961-1990) show that during the 2091-2099 period, $170.42 \%$ precipitation occurrence is predicted (Fig. 8(a-b)). These results expect extreme flash floods in the region. During the reported period (20912090), the reservoirs, ponds and small dams could potentially be filled with water, and the study area is expected to be covered with highly agriculture production. Groundwater quality is expected to improve due to fresh aquifers recharge. More land would cover under agriculture practice and employment opportunities in the water sector would be increased. Hence, no water deficit through hill torrents and groundwater potential is anticipated.

For the projected period (2021-2099), the precipitation trend shows shortfall of $0.95,12.58,53.98$ and 51.80 percent during 2021-2030, 2031-2040, 2041-2050 and 2081-2090 
respectively, while the increasing trend of precipitation is projected 60.411 and $70.422 \%$ during the period of 2071 -

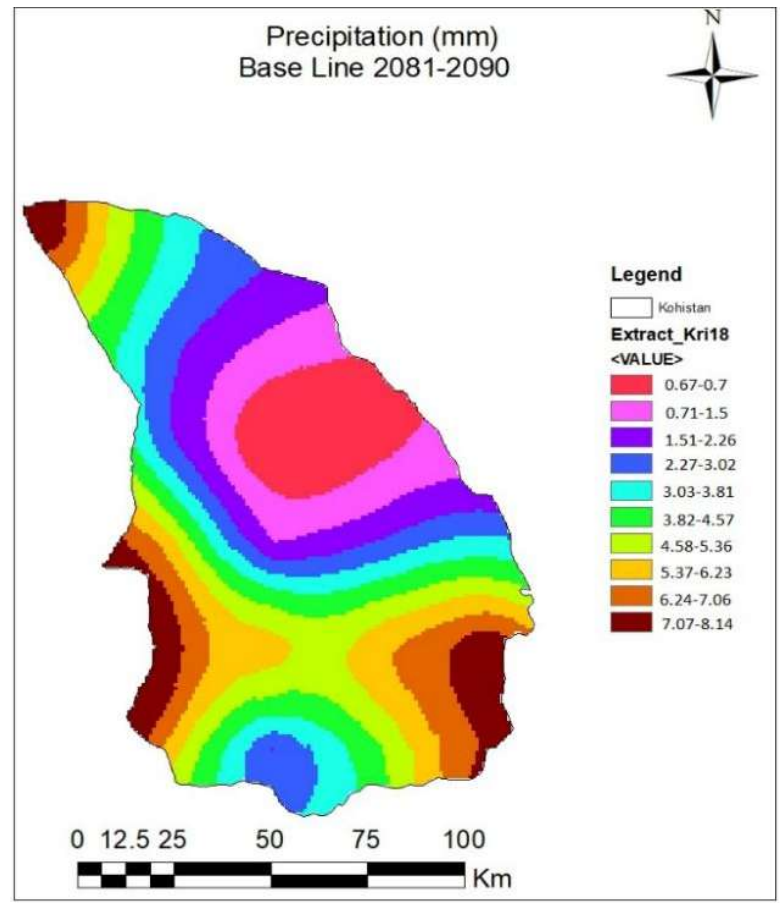

FIG. 7(a). AVERAGE PRECIPITATION IN THE STUDY AREA OVER (2081-2090) PERIOD

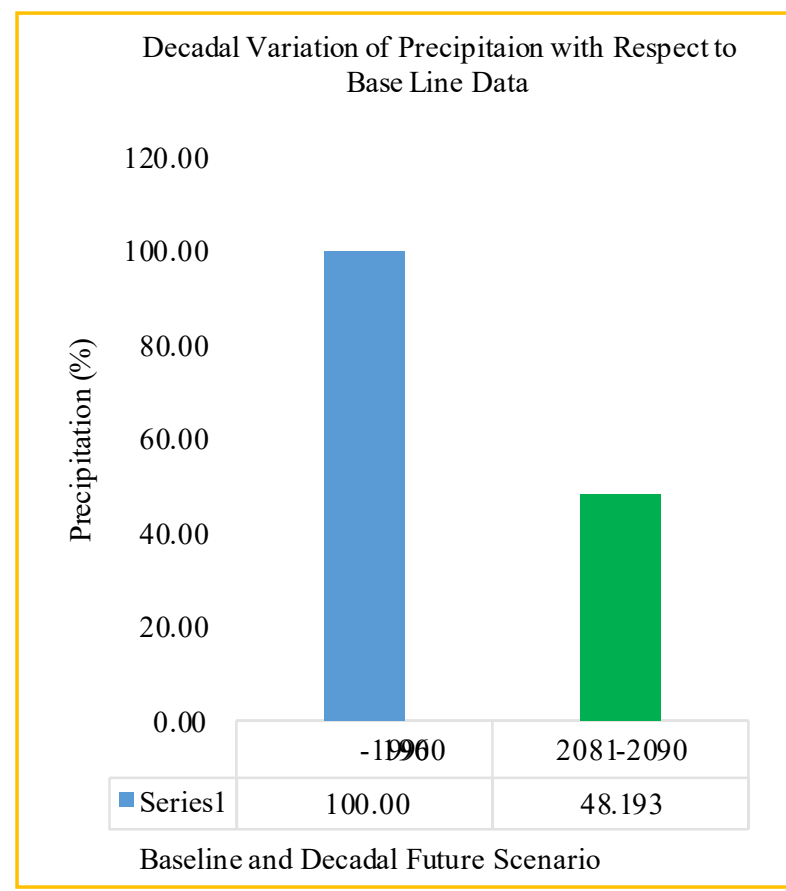

FIG. 7(b). PRECIPITATION SHORTFALLS COMPARED TO THE BASELINE SCENARIO
2080 and 2091-2099 respectively over the baseline period 1961-1990 in the study area (Fig. 9).

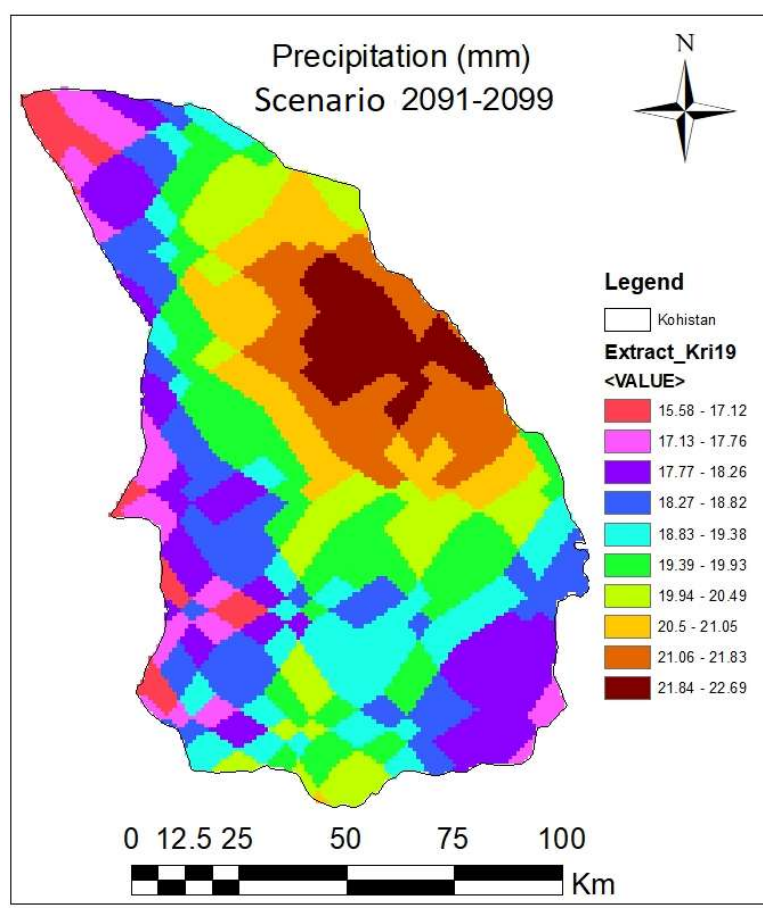

FIG. 8(a). AVERAGE PRECIPITATION IN THE STUDY AREA OVER (2091-2099) PERIOD

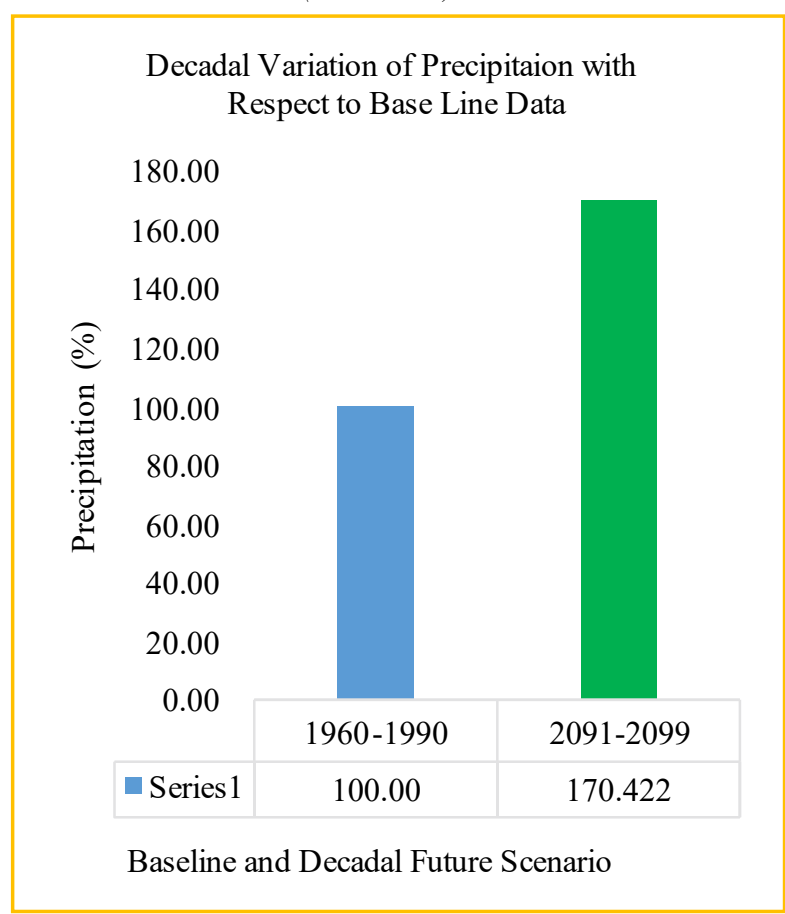

FIG. 8(B). PRECIPITATION SHORTFALLS COMPARED TO THE BASELINE SCENARIO

Mehran University Research Journal of Engineering \& Technology, Volume 38, No. 2, April, 2019 [p-ISSN: 0254-7821, e-ISSN: 2413-7219] 


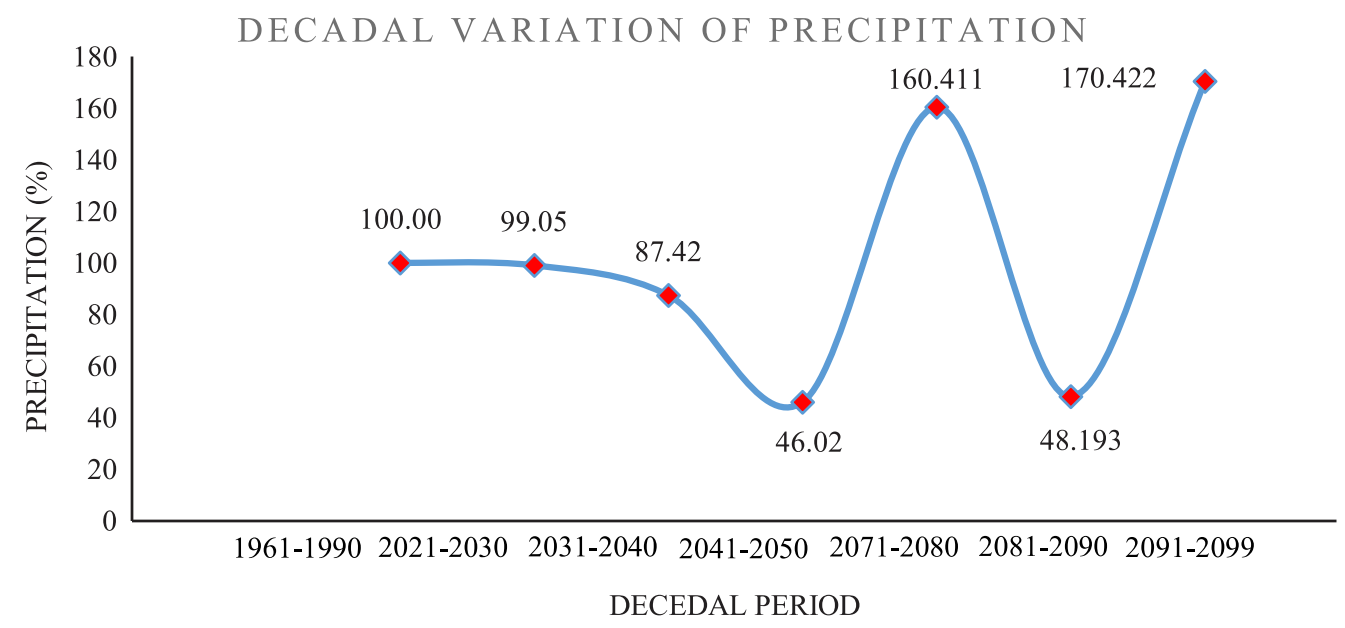

FIG. 9. PROJECTED DECADAL PERCENTAGE PRECIPITATION CHANGE OVER THE (2021-2050 AND 2071-2099) PERIOD COMPARED TO THE BASELINE (1961-1990) PRECIPITATION DATA

\section{CONCLUSION}

The study showed that during the projected period (20212050 and 2071-2099); there are cumulative threats of inconsistency in precipitation that may cause extreme floods and droughts. The baseline precipitation shortage vacuum was not replenished during 2031-2051 and 20812090, while, during 2021-2030 was estimated the negligible impact on the hill torrents and groundwater recharge.Besides the adverse impact on water resources, including hill torrents and groundwater quality, food security and human health will be at risk. However, the remaining two decades 2071-2080 and 2091-2099 shown vice versa situation and projected extreme flood, by more precipitation trend about $60.50-70.50 \%$ as compared to the baseline period 1961-1990. The Water resources of the study area are depending on hill torrents and the shallow aquifers developed on the torrential banks and recharges the groundwater immediately after precipitation occurrence. As per literature review, precipitation generates $30 \%$ of run-off on each shower of $12 \mathrm{~mm}$ or exceeding quantity. That means $70 \%$ of the precipitation infiltrates into the soil, and the percolation contributes to enhance the groundwater recharge and improve the quality of water. More contribution of recharge water receives the adjoining parts of the torrents, that's why the shallow aquifers are developed contiguous the natural streams. On the basis of the above results, the study area would have water resources challenges in the future, because of drought, disastrous and dangerous flood situations are forecasted in the region.

\section{RECOMMENDATIONS}

The recommendations are based on the above-concluded results, that the global warming would adversely affect on the natural resources in the forthcoming period, to combat these situations, more infrastructures with adequate planning would be developed in the region to face the projected situations. The storage infrastructure could be used to capture the excess runoff water and beneficial to recharge the groundwater. The water management strategies would be integrated with water stress or abundant water situations in the study area. If the projection showed more wet events, the runoff volume might be stored, and utilized with efficient resources according to the need. Consequently, the stored water recharges the groundwater aquifers. Besides, that the drought spell would combat with stored water, would be used more efficiently with advanced techniques of HEIS

Mehran University Research Journal of Engineering \& Technology, Volume 38, No. 2, April, 2019 [p-ISSN: 0254-7821, e-ISSN: 2413-7219] 
(High-Efficiency Irrigation System), and smart irrigation water saving techniques. Which requires better planning and more reservoirs to store the run-off water for water resources development in the region. Nevertheless, predictions of future climate offer a wider image to planners and policymakers for adaptation and mitigation.

\section{FUTURE WORK}

The domain of current research work is the projection of rainfall variability through the PRECIS regional model. Besides, that the projected data, will further be used to estimate rainfall run-off relationship on the annual and monthly basis in the next phase of research. For this purpose, a hydrological model would be used.

\section{ACKNOWLEDGMENT}

Acknowledge, the Hadley Centre for Climate Science and Services Met Office, UK, and Pakistan Meteor Local Department, to empower the authors on the access of PRECIS Regional Climate Model, for research aspects.

\section{REFERENCES}

[1] Victor, O., Haishan, C., and Chujie, G., "Projected Changes in Mean Rainfall and Temperature Over East Africabased on CMIPS5 Models", International Journal of Climatology, Volume 38, pp.1375-1392, 2018. https:/ /rmets.onlinelibrary.wiley.com/doi/epdf/10.1002/ joc. 5252

[2] Kreft, S., Eckstein, D., Junghans, L., Kerestan, C., and Hagen, U., "Global Climate Risk Index-2015", Briefing Paper, GERMANWATCH, pp.1-32, November 2014,http://germanwatch.org/de/download/8551.pdf

[3] Noshriwani, M., "Climate Change and Its Impact on Gender in Rural areas of Sindh, Pakistan", IUCN Report, 2016.https://www.iucn.org/news/commissionenvironmental-economic-and-social-policy/201608/ climate-change-and-its-impact-gender-rural-areas-sindhpakistan
[4] Ansari, A.K., "Proceedings of Consultative Workshop on Indus Delta Eco-Region IDER”, pp 39-46, December, 16-19, 2002. http://www.academia.edu/12187151/ MANGROVES_OF_THE_ACTIVE_INDUS_DELTA_

[5] Jianqiang, R, and Zhongxin, C., "Regional Yield Estimation for Winter Wheat with MODIS-NDVI Data in Shandong, China", International Journal of Applied Earth Observation and Geo-Information, Volume 10, No.4, pp. 403-413, 2008.

[6] Muhammad, A.K., and Tahira, S., "Impacts of Hil Torrents Management on Socio-Economic Conditions of Arid Land Farmers: A Case Study of Tehsil DG Khan", Asian Journal of Humanity, Art and Literature, Volume 1, No. 3, 2014.

[7] Akhtar,M., Ahmad, N., and Booij, M., "The Impact of Climate Change on the Water Resources of HindukushKarakorum-Himalaya Region under Different Glacier Coverage Scenarios", Journal of Hydrology, Volume 355, pp. 148-163, 2008.

[8] Bosshard, P., "No Bargain for Indus Delta. Fisher Folk", Pakistan Fisher Folk Forum, pp.40-41, 2006.

[9] Khan, M.A., "Climate Change Research in Pakistan, Regional Conference on Climate change: Challenges and Opportunities for South Asia",Regional Conference on Climate Change: Challenges and Opportunities for South Asia Islamabad, 13-14 January 2009. https:// www.iucn.org/sites/dev/files/import/downloads/ pres_arshad_khan.pdf

[10] Rasul, G., Mahmood, A., Sadiq, A., and Khan, S.I. "Vulnerability of the Indus Delta to Climate Change in Pakistan", Pakistan Journal of Meteorology Volume8, No. 16, pp. 89-107, 2012.

[11] Robert, G., Brakenridge, J., Day, W.J., Liviu, G., Mark, T.H, Philip, R.H, Hood, W.G., Kelman, I., Kettner, A.J., Hartwig, H.K., Nicholls, R., Paola, C., Juan, D., Restrepo, Y.S., Alex de, S., Charles, S., Charles, J.V., and Juergen, W., "Dynamics and Vulnerability of Delta Systems", GKSS Research Center LOICZ International Project Office Institute for Coastal Research MaxPlanck-Strasse 1 D-21502 Geesthacht, Germany, LOICZ Reports and Studies No. 35. 2009. https://www.researchgate.net/ publication/259527047_Dynamics_and_Vulnerability_ of_Delta_Systems 
[12] Robin, M.L., and James, L.W., "Environmental Impacts of Climate Change and Water Development in the Indus Delta Region",Water Resources Development,Volume9, No. 3, 1993 http://www.tandfonline.com/doi/pdf/ $10.1080 / 07900629308722587$

[13] Bhaskaran, B., Jones, R., Murphy, J., and Noguer, M., "Simulations of the Indian Summer Monsoon Using a Nested Regional Climate Model", Domain Size Experiments, Volume12, No.9, pp.573-587, 1996.https:/ /link.springer.com/article/10.1007\%2FBF00216267

[14] Dash, S., Shekhar, M., and Singh, G., "Simulation of Indian Summer Monsoon Circulation and Rainfall Using RegCM3",Theoretical and Applied Climatology Volume, 86, pp. 161-172, 2006. https://link.springer.com/ content/pdf/10.1007/s00704-006-0204-1.pdf

Bhaskaran, B., Ramachandran, A., Jones, R., and Moufouma-Okia, W., "Regional Climate Model Applications on Sub-Regional Scales Over the Indian Monsoon Region", The Role of Domain Size on Downscaling Uncertainty, Journal of Geophysical Research, Volume, 117, pp. 1-12, 2012. https:// agupubs.onlinelibrary.wiley.com/doi/pdf/10.1029/ 2012JD017956

[16] Dimri, A., Yasunari, T., Wiltshire, A., Kumar, P., Mathison, C., Ridley, J., and Jacob, D., "Application of Regional Climate Models to the Indian Winter Monsoon Over the Western Himalayas", Science Total Environment, Volume, 468, No. 469, pp. S36-S47, 2013. https://www.sciencedirect.com/science/article/pii/ S0048969713000594

[17] Ospina, A.V., and Heeks, R., "Unveiling the Links between ICTs \& Climate Change in Developing Countries", A Scoping Study, Centre for Development Informatics, Manchester, UK, 2010. https:// www.giswatch.org

[18] Nigel, W.A "Climate Change and Global Water Resources: SRES Emissions and Socio-Economic Scenarios", Global Environmental Change, Volume 14, No.1, pp. 31-52, 2004.

[19] Kioutsioukis, I., Melas, D., and Zerefos, C., "Statistical Assessment of Changes in Climate Extremes Over Greece (1955-2002)", International Journal of Climatology, Volume30, pp. 1723-1737, 2010.http://www.gnest.org/ proceedings/cest2013/public_html/papers/0470.pdf.
[20] Archer, D., and Fowler, H., "Using Meteorological Data to Forecast Seasonal Runoff on the River Jhelum", Pakistan, Journal of Hydrology, Volume361, pp. 10-23, 2008. https://www.sciencedirect.com/science/article.

[21] Taylor, M.A., Centella, A.C., Borrajero, J., Benzanilla, I., Campbell, J., Rivero, R., Campbell, S.T.S.F, Whyte, and Watson, F.R., "Glimpses of the Future: A Briefing from the PRECIS Caribbean Climate Change Project", Caribbean Community Climate Change, Belmopan, Belize, 2007. http://precis.metoffice.com/docs/ CCCCC_PRECIS_REPORT.pdf

[22] Natcom, India., "India's Second National Communication to the UN Frame Work Convention on Climate Change Work Programme", Ministry of Environment and Forests, New Delhi, India, 2008. http://www.in.undp.org/ content/dam/india/docs/united_nations_framework_ convention_on_climate_change.pdf

[23] Alves, L., and Marengo, J., “Assessment of Regional Seasonal Predictability Using the PRECIS Regional Climate Modeling System Over South America", Theoretical and Applied Climatology, Volume100, pp. 337-350, 2010.

[24] Pall, P., Aina, T., Stone, D.A., Stott, P.A., Nozawa, T., Hilberts, A.G.J., Lohmann, D.,Allen, M,R., "Anthropogenic Greenhouse Gas Contribution to Flood Risk in England and Wales in Autumn 2000", Nature, Volume470, pp. 382-385, 2011.

[25] Kumar, R.K., Sahai, A.K., Kumar, K.K., Patwardhan, S.K., Mishra, P.K., Revadekar, J.V., Kamala, K., and Pant, G.B., "High Resolution Climate Change Scenarios for India for the 21 st Century", Current Science, Volume90, pp. 334-345, 2006.

[26] Xu, Y.L., Huang, X.Y., Zhang, Y., Lin, W.T., and Lin, E.D., "Statistical Analyses of Climate Change Scenarios Over China in the 21st Century", Advances in Climate Change Research, Volume 2 (Supplementary-1), pp. 5053, 2006.

[27] Xu, Y.L., Zhang, Y., Lin, E.D., Lin, W.T., Dong, W.J., Jones, R., Hassell, D., and Wilson, S., "Analyses on the Climate Change Responses Over China under SRES B2 Scenario Using PRECIS", Chinese Science Bulletin, Volume 51, No. 18, pp. 2260-2267, 2006. 
[28] Zhang, Y., Yinlong, X., Wenjie, D., Lijuan, C., and Sparrow, M., "A Future Climate Scenario of Regional Changes in Extreme Climate Events Over China Using the PRECIS Climate Model", Geophysical Research Letters, Volume 33, pp.1-6, 2006. https://agupubs. onlinelibrary.wiley.com/doi/epdf/10.1029/2006 GL027229

[29] Marengo, J.A., Jones, R., Alves, L.M., and Valverde, M.C.,"Future Change of Temperature and Precipitation Extremes in South America as Derived from the PRECIS Regional Climate Modeling System", International Journal of Climatology, Volume 29, pp. 2241-2255 [DOI:10.1002/joc.1863], 2009.

[30] Van, der, S.G., Rasmijn, L., Barkmeijer, J., Sterl, A., and Hazeleger, W.,"The 2010 Pakistan Floods in a Future Climate", Climatic Change, Volume 148, No.1, pp.205-218, [DOI: 10.1007/s10584-018-2173-7], May, 2018.
[31] Dong, Q., and Eerens, H., "Crop Area Assessment Using Remote Sensing on the North China Plain", The International Archives of the Photogrammetry, Remote Sensing, and Spatial Information Sciences, Volume, XXXVII, Part-B8. pp.957-962, 2008,

[32] Im, E., Kim, M., Kwon, W., and Cocke, S., "Projected Change in Mean and Extreme Climate Over Korea from a Double-Nested Regional Climate Model Simulation", Journal of Meteorological Society of Japan, Volume 85, pp.717-732, 2007.

[33] Babaeiana, R., Modiriana, M., and Zarghami, M., "Simulation of Climate Change in Iran during 20712100 Using PRECIS Regional Climate Modelling System”, Desert, Volume 20, No. 2, pp.123-134, 2015. 